\title{
ANALISIS PENGARUH PERFORMA TERHADAP VORTEX CYCLONE PADA SEPEDA MOTOR
}

\author{
AMIR $^{1}$, EFRIZAL $^{2}$, ERIK SETYAWAN $^{3}$ \\ Program Studi Teknik Mesin, Fakultas Teknik, Universitas Muhammadiyah Tangerang \\ Jl. Perintis Kemerdekaan I/33 Cikokol-Tangerang \\ E-Mail : amirduta815@gmail.com
}

\begin{abstract}
ABSTRAK
Penelitian ini bertujuan untuk mengetahui performa yang dihasilkan jika motor 110 cc menggunakan vortex cyclone. Untuk mengetahui perbandingan bahan bakar pada motor 110 performance untuk mengetahui daya dan torsi pada motor Honda matic $110 \mathrm{cc}$. Bahan yang digunakan vortex cyclone. Alat yang digunakan untuk uji performa yaitu computer, dynamometer, blower, dan exhaust. Dari hasil pengaruh performa motor $110 c c$ menggunakan vortex cyclone yang telah dilakukan, maka dapat diambil kesimpulan sebagai berikut : Setelah dilakukan pengujian performa daya pada motor automatic fuel injection 110cc jika menggunakan Vortex cyclone di Dynotest dapat diketahui perubahan daya dan torsi pada motor 110cc. Dan dari hasil pengujian yang dilakukan oleh penulis terhadap penggunaan bahan bakar dengan menggunakan Vortex cyclone dan tidak menggunakan Vortex Cyclone, terjadi perubahan yang signifikan pada saat motor automatic fuel injection 110cc jika menggunakan Vortex cyclone terjadi keiritan penggunaan bahan bakar. cc jika menggunakan vortex cyclone. Jenis penelitian yang di lakukan adalah penelitian experiment.
\end{abstract}

Kata Kunci : Performa; Vortex Cyclone; Motor 110cc; Daya; Torsi; Bahan Bakar.

\begin{abstract}
This study aims to determine the resulting performance if a $110 \mathrm{cc}$ motorcycle uses a vortex cyclone. To find out the comparison of fuel on a 110 performance motorbike to find out the power and torque on a 110 cc Honda matic motorbike. The material used is a vortex cyclone. The tools used to test the performance are Computer, dynamometer, blower, and exhaust. From the results of the influence of the performance of a 110cc motor using a vortex cyclone that has been carried out, the following conclusions can be drawn: After testing the power performance on a 110cc automatic fuel injection motor when using a Vortex cyclone in Dynotest it can be seen changes in power and torque on a $110 \mathrm{cc}$ motor. And from the results of the tests carried out by the author on the use of fuel using a Vortex cyclone and not using a Vortex Cyclone, there was a significant change when the 110cc automatic fuel injection motorcycle used a Vortex Cyclone, there was a fuel economy efficiency. $c c$ if using a vortex cyclone. The type of research carried out is experimental research
\end{abstract}

Keywords: Performance; Vortex Cyclone; 110cc Motor; Power; Torque; Fuel.

\section{PENDAhuluan}

Sepeda motor merupakan alat transportasi yang digerakkan oleh mesin berbahan bakar bensin. Mesin sepeda motor memerlukan jenis bahan bakar yang sesuai dengan desain mesin itu sendiri agar dapat bekerja dengan baik dan menghasilkan kinerja yang optimal, untuk pemakaian sepeda motor tentunya tidak lepas dari pemakaian jenis bahan bakar yang digunakan untuk memperoleh kinerja mesin yang optimal diantaranya daya dan torsi. Secara umum, ada 4 tuntutan teknologi kendaraan yang harus di penuhi sekarang ini, yaitu: (1) harus dapat performa yang tinggi (high performance), (2) harus dapat menghemat pemakaian bahan bakar (fuel economic), (3) harus dapat menghasilkan suara dan getaran yang rendah (low noise and vibration) dan , (4) harus dapat menghasilkan emisi gas buang yang rendah (low emission).

Salah satunya adalah campuran antara udara dan bahan bakar yang tidak homogen, sehingga menyebabkan sebagian campuran udara dan bahan bakar tidak ikut terbakar dengan sempurna.

Menurut pendapat Hidayat (2012: 22), sumber tenaga mesin hanyalah mengubah campuran udara dan bahan bakar menjai energi gerak berputar, yang sering diukur dengan Horse Power (HP). Campuran udara dan bahan bakar yang dikabutkan oleh karburator atau injector akan mengalir kedalam ruang bakar yang selanjutnya akan dikompresi dan dibakar didalam silinder.

Menurut pendapat Hidayat (2012:14) bahwa prinsip kerja motor bensin adalah mesin yang bekerja memanfaatkan energi dari gas panas hasil proses pembakaran, dimana proses pembakaran berlangsung 
di dalam silinder mesin itu sendiri, sehingga gas pembakaran sekaligus berfungsi sebagai fluida kerja menjadi tenaga atau energi panas.

Menurut pendapat Hidayat (2012:14), Prinsip kerja motor bensin adalah mesin penggerak yang memanfaatkan hasil pembakaran bahan bakar dan udara dalam ruang silinder yang akan menimbulkan pergerakan translasi oleh piston dan akan diubah menjadi gerak rotasi oleh poros engkol dan sebaliknya gerak rotasi poros engkol akan diubah menjadi gerak translasi oleh piston dan seterusnya.

\section{METODOLOGI PENELITIAN}

Penelitian ini dilakukan di bengkel Motori Rumahnya Bikers yang beralamatkan di jalan Mangga 16 Blok CC no.37B, duri kepa Jakarta Barat, Jakarta, Indonesia 11510. Waktu penelitian pada tanggal 10 November 2020 pukul 10:00-12:30 WIB.

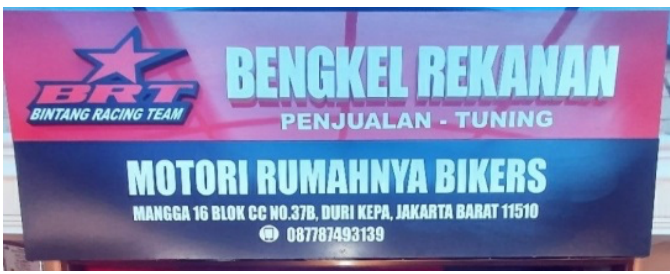

Gambar 1. Bengkel Motori Rumahnya Bikers.

Objek penelitiannya adalah sepeda Motor Scoopy 110 cc Tahun 2014 dengan spesifikasi pada Tabel 1.

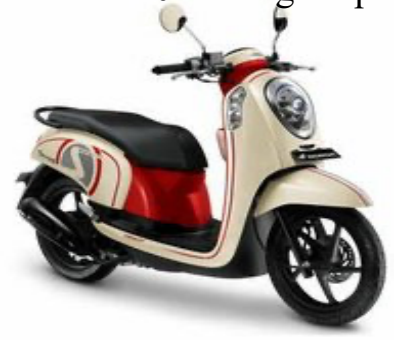

\section{Gambar 2. Motor automatic fuel injection pgm-fi $110 \mathrm{cc}$}

Alat yang digunakan pada penelitian ini adalah vortex cyclone yang dipakai adalah vortex cyclone dengan jenis jet ranger, pada pengujian ini penulis menggunakan vortex cyclone dengan jenis jet ranger yang memiliki 6 sirip

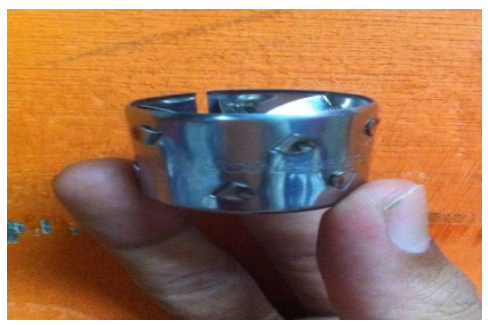

Gambar 3. Vortex Cyclone
Table 1. Spesifikasi Motor Honda Scoopy 110

\begin{tabular}{|c|c|}
\hline TIPE MESIN & 4-Langkah, SOHC \\
\hline SUSUNAN SILINDER & Cylinder Tunggal \\
\hline $\begin{array}{c}\text { DIAMETER X } \\
\text { LANGKAH }\end{array}$ & $50 \times 55 \mathrm{~mm}$ \\
\hline $\begin{array}{c}\text { PERBANDINGAN } \\
\text { KOMPRESI }\end{array}$ & $9,2: 1$ \\
\hline VOLUME SILINDER & $110 \mathrm{cc}$ \\
\hline DAYA MAKSIMUM & $\begin{array}{c}6,7 \mathrm{~kW}(8,52 \mathrm{PS}) / \\
8.000 \mathrm{rpm}\end{array}$ \\
\hline TORSI MAKSIMUM & $\begin{array}{c}8,68 \mathrm{Nm}(0,89 \mathrm{kgf.m}) \\
/ 6.500 \mathrm{rpm}\end{array}$ \\
\hline SISTEM STARTER & $\begin{array}{c}\text { Electric Starter \& } \\
\text { kick starter }\end{array}$ \\
\hline $\begin{array}{c}\text { SISTEM } \\
\text { PELUMASAN }\end{array}$ & wump \\
\hline
\end{tabular}

Proses Pemasangan vortex cyclone pada sepeda motor Honda scoopy antara lain sebagai berikut :

1) Membuka tutup filter menggunakan obeng + (Plus).

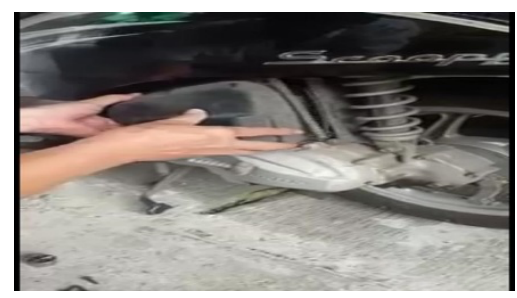

Gambar 4. Baut Filter dan Obeng Plus

2) Langkah selanjutnya, melepas tutup filter dan memasang vortex cyclone pada karet filter.

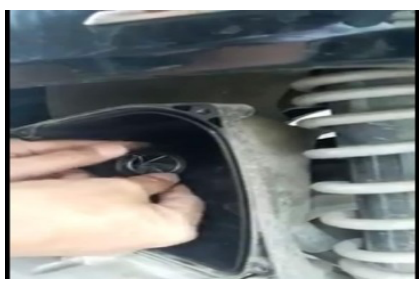

Gambar 5. Pemasangan Vortex Cyclone

Setelah vortex cyclone terpasang pada karet filter tutup kembali cover filter dan sepeda motor siap digunakan.

Alat - alat bantu penelitian yang lain digunakan dalam pemasangan vortex cyclone ini adalah dynotest inersia merk super dyno inersia 501 , tachometer dan speedometer yang berfungsi untuk mengetahui diagram atau grafik putaran mesin yang diteliti. 


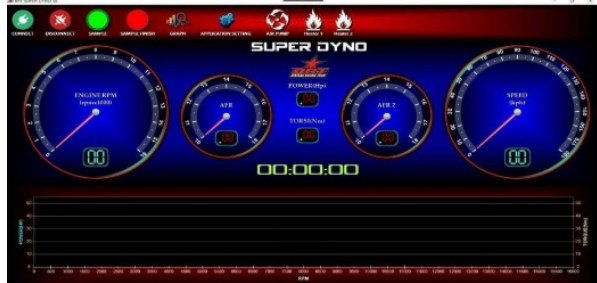

Gambar 6. Dynotest SUPER DYNO INERSIA 50

\section{BRT.}

Langkah - langkah penelitian ditulis dalam bentuk urutan proses yaitu sebagai berikut:

1. Pastikan Vortex cyclone yang akan digunakan sesuai dan cukup untuk proses pengujian.

2. Mesin motor dinyalakan untuk dilakukan pemanasan, yaitu pada posisi idle speed.

3. Kendaraan bermotor di run sebanyak 15 kali diatas dynotest untuk mencari nilai

4. Melakukan power test menggunakan dynotest pada kendaraan bermotor dengan RPM yang ditentukan yaitu $5500>9500$ RPM dengan menggunakan Vortex Cyclone.

5. Analisa hasil penelitian.

\section{HASIL DAN PEMBAHASAN}

Hasil pengujian performa motor automatic fuel injection 110cc (Standar) adalah berupa daya yang di dapat melalui pengujian dengan menggunakan alat dynotest, berikut adalah data dari hasil spesifikasi motor standar yang telah di lakukan pengujian.

\subsection{Performa Daya Dan Torsi Yang Dihasilkan} Jika Motor 110 Ce Menggunakan Vortex

\section{Cyclone}

Berikut adalah data performa daya dan torsi motor automatic fuel injection $110 \mathrm{cc}$ jika menggunakan Vortex cyclone pada Gambar 7.

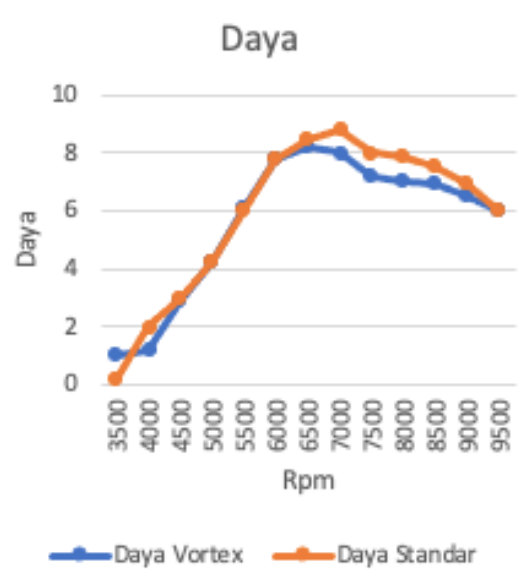

Gambar 7. Grafik Daya Motor Standard dan Menggunakan Vortex Cyclone
Setelah dilakukan pengujian performa daya pada motor automatic fuel injection 110cc jika menggunakan Vortex cyclone di Dynotest dapat diketahui perubahan daya dan torsi pada motor $110 \mathrm{cc}$ dapat dilihat pada Gambar 7 dan 8 .

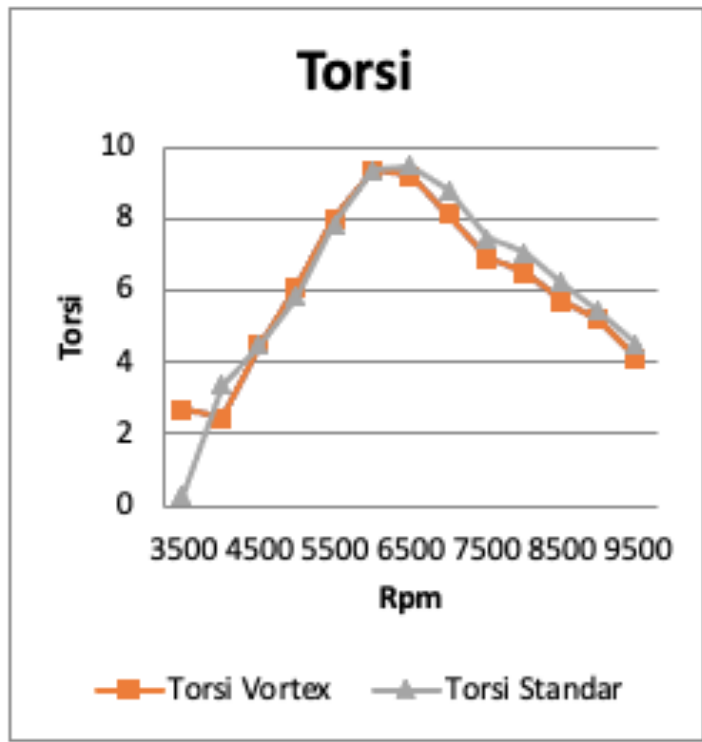

Gambar 8. Grafik Torsi Motor Standard dan Menggunakan Vortex Cyclone

\subsection{Perbandingan Bahan Bakar Pada Motor 110 Cc Jika Menggunakan Vortex Cyclone}

Berikut adalah data perbandingan penggunaan bahan bakar pada motor automatic fuel injection $110 \mathrm{cc}$ jika menggunakan Vortex cyclone dan tidak menggunakan Vortex cyclone antara lain :

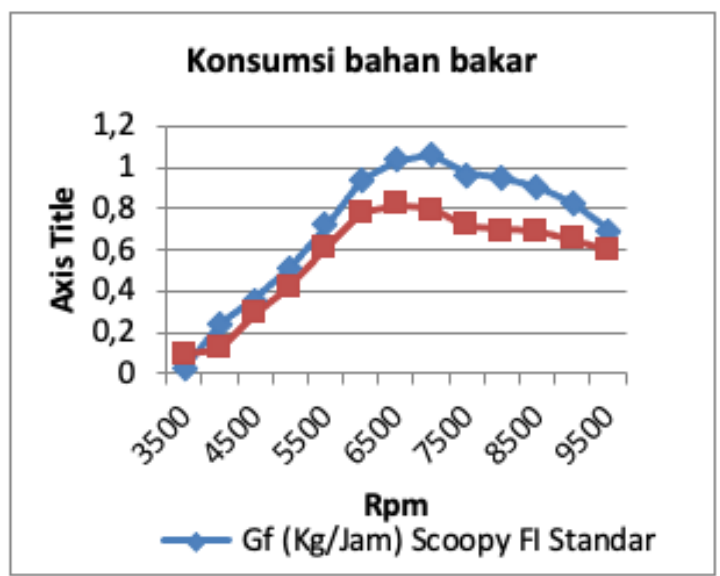

Gambar 9. Grafik Perbandingan Penggunaan Bahan Bakar Menggunakan Vortex Cyclone

Dari hasil pengujian yang dilakukan oleh penulis terhadap penggunaan bahan bakar dengan menggunakan Vortex cyclone dan tidak menggunakan Vortex Cyclone, terjadi perubahan 
yang signifikan pada saat motor automatic fuel injection $110 \mathrm{cc}$ jika menggunakan Vortex cyclone terjadi keiritan penggunaan bahan bakar. Dapat dilihat pada Gambar 9.

\section{KESIMPULAN}

Dari hasil pengaruh performa motor $110 \mathrm{cc}$ menggunakan vortex cyclone yang telah dilakukan, maka dapat diambil kesimpulan sebagai berikut :

1. Setelah dilakukan pengujian performa daya pada motor automatic fuel injection $110 \mathrm{cc}$ jika menggunakan Vortex Cyclone di Dynotest dapat diketahui perubahan daya dan torsi pada motor $110 \mathrm{cc}$.

2. Dari hasil pengujian yang dilakukan oleh penulis terhadap penggunaan bahan bakar dengan menggunakan Vortex Cyclone dan tidak menggunakan Vortex Cyclone, terjadi perubahan yang signifikan pada saat motor automatic fuel injection 110cc jika menggunakan Vortex Cyclone terjadi keiritan penggunaan bahan bakar.

\section{DAFTAR PUSTAKA}

Arismunandar Wiranto (1988), "Penggerak Mula Motor Bakar Torak. Bandung penerbit ITB

Astra Honda Motor. (1995)."Modul buku panduan PGM-FI. (Programmed Fuel Injection)" Jakarta PT. Astra Honda Motor

Bambang Setyonno, Desmas Arifianto, Efrita Arfah Zuliari, Satria Mahdum Purbo Waseso. "Desain Dan Analisis Performasi Sistem Penggerak Purwarupa Kendaraan Hibrid Bertenaga Udara Dan Listrik"Bed 18" Menggunakan "Scotch Yoke Mechanism” Jurnal Iptek vol.23 No. 1 Mei 2019.

Fx. Sukidjo. Performa Mesin Pada Motor Empat Langkah Berbahan Bakar Premium Dan Pertamax. Forum Tenik vol.34 No.1, januari 2011.

Farid Majedi, Indah Puspitasari. "Optimasi Daya Dan Torsi Pada Motor 4 Tak Dengan Modifikasi Crankshaft Dan Porting Pada Cylinder Head". Jurnal Teknologi Terpadu vol.5 No. 1 April 2017.

Heywood Jhon B (1998), Internal Combustion Engine Fundamentals", McGraw Hill Book Company, New York

I Nyoman Sutantra Bambang Sampurno (2010), "Teknologi Otomotif". Penerbit Guna Widya, Surabaya

James D. Halderman, Jim Linder (2009). "Automotive Fuel And Emissions Control System" (second edition) : Prentice Hall Upper Saddle, New Jersey Columbus, Ohio
Khovakh (1976). "Motor Vehicles Engine". Moscow. Mr.Publiser 